\title{
The Effect of Preliminary Test to Cognitive Learning Competency of Biology Students in the Inquiry Learning Model in Class VIII Junior High School (SMP Negeri 12) Padang
}

\author{
Essa Maurisni ${ }^{1 *}$ Yuni Ahda ${ }^{1}$ \\ ${ }^{1}$ Dept. of Biology, Faculty of Mathematics and Science (FMIPA), Universitas Negeri Padang, Padang, Indonesia \\ *Corresponding author. Email: maurisnie88@gmail.com
}

\begin{abstract}
This research began with unsatisfactory biology learning outcomes. This is due to students having not mastered the subject matter, there needs to be a solution so that students get good learning outcomes. The inquiry learning model is used by adjusting the 2013 curriculum which gives students the opportunity to learn. The initial ability of students needs to be known by the teacher before starting learning, to find out whether students have knowledge before participating in learning. This research is a quasi-experimental study. The population of this study were students of class VIII 12 of SMP Negeri 12 Padang who were registered in the 2018/2019 school year. Sampling was done using Simple Random Sampling technique and obtained class VIIIA as an experimental class and class VIIIC as a control class. The instrument used was an objective test. Data analysis techniques to test hypotheses are t-test and two-way anova test. From the results of the study show that the cognitive competence of learning students who learn with inquiry learning models is better than the competence of cognitive domain learning students who follow conventional learning. There is no interaction between the use of inquiry learning models and the initial ability of students' cognitive learning competencies.
\end{abstract}

Keywords: Inquiry, Initial Ability, Competence of Cognitive Domains of Students

\section{INTRODUCTION}

The implementation of the 2013 curriculum in the field of education aims to produce Indonesian people who are productive, creative, innovative, faithful and devoted to God. 2013 curriculum development focused on competence and character formation of students a blend of knowledge, skills and attitudes that can be applied learners so that they can keep abreast of the times.

The 2013 curriculum learning process is student-centered learning. Student-centered learning can activate students in learning; learners can understand the lesson through what is learned in the learning process. The teacher plays an important role in designing lessons to be carried out an effective and enjoyable learning process.

The use of learning methods that are less desirable by students will affect student learning outcomes. The process of learning biology in SMP Negeri 12 Padang can be observed in Table 1, but not all of them produce good grades in the sense that there are still many students who do not meet the minimum completeness criteria (KKM) of biology in class VIII which is set at 75 .

Table 1. Number of Learners and the Average Value of Daily Tests for Grade VIII Students in Semester 1 Middle School 12 Padang.

\begin{tabular}{|l|c|l|l|l|}
\hline Class & Mean & $\begin{array}{l}\text { Number } \\
\text { of } \\
\text { Student }\end{array}$ & $\begin{array}{l}\text { Learners } \\
\text { who } \\
\text { passed } \\
(\%)\end{array}$ & $\begin{array}{l}\text { Learners } \\
\text { who didn't } \\
\text { passed (\%) }\end{array}$ \\
\hline VIII A & 70.92 & 31 & 35.71 & 62.97 \\
\hline VIII B & 74.11 & 30 & 40.75 & 57.15 \\
\hline VIII C & 72.35 & 31 & 35.71 & 64.29 \\
\hline
\end{tabular}

Learning competencies that are owned by each student in learning varies. Often teachers pay less attention to the students' initial abilities so the teacher knows the characteristics of the students. The initial ability of 
students is the ability that students have had before they take part in learning. This is useful to know whether students have prerequisite knowledge to participate in learning and the extent to which students already know the material to be presented, so that teachers can design learning better.

The initial ability is used not only for harmony in the learning process, but also has another important role. Initial ability is very important role in increasing the meaningfulness of teaching, which in turn has an impact in facilitating internal processes that take place in students when learning[1]. One of the benefits that can be obtained from the results of student studies that we will face in the classroom is that we obtain a complete and detailed picture of the students' initial competencies / abilities that function as prerequisite for new material that will be delivered[2]. Based on these explanations it appears that initial ability has an important role in learning.

The most appropriate technique to determine students' early abilities is the test technique. Where is a test to find out how far students have knowledge or skills regarding the lessons being taken.

Inquiry comes from English inquiry which means "the process of asking and finding out answers to scientific questions asked". Inquiry learning model is a scientific learning model or known as scientific inquiry (scientific inquiry learning model) is one of the models and is conducive for implementing a constructive approach[3].

The inquiry learning model is a powerful learning approach in instilling the foundations of scientific thought in students to encourage students to learn more and develop their creativity in analyzing problems, further investigation is useful to increase the value of attitudes that are very necessary to enable students to think scientifically.

Inquiry is a learning approach that uses steps in sequence, as experts use this approach in conducting experiments. The inquiry model in learning biology allows students to learn and do as scientists do. Students will be directed to learn biological concepts and be able to take a scientific approach, combine abilities and empower students. Students will play an active role in learning with the encouragement of teachers, with activities focused on solving problems.

Learning competence is a criterion that must be possessed by students after experiencing the learning process. Competencies were classified into three domains, namely the cognitive domain, the psychomotor domain and the affective domain[4].

Knowledge or cognitive competency assessment is an assessment conducted by the teacher to measure the level of achievement or mastery of students in aspects of knowledge that includes memory or memorization, understanding, application or application, analysis, synthesis, and evaluation[5].

There are several problems that cause the low biology learning outcomes of students in 12 State Junior High Schools in Padang: 1) students have not been optimally involved in the learning process, 2) teachers rarely test the students' initial ability, and 3) the science learning competency of students is still low.

From the problems above, this study is limited by: 1) the learning competency to be studied is the cognitive domain competence, 2) the material to be used in this study is the respiratory system, 3 ) the initial ability of students.

Whereas for the formulation of the problems of this study are 1) whether the cognitive competence of learning students who learn with inquiry models is higher than the cognitive domain of learning competencies of students who learn with student books ?,2) whether the learning competence of cognitive domains of capable students High initial use of inquiry learning models is higher than the cognitive learning competence of students who have high initial learning abilities with student books, 3) Is the cognitive competence of learning students who have low initial knowledge of learning using the inquiry learning model higher than competence learning cognitive domains of students who are capable of low initial learning with student books? and 4) is there an interaction between the use of inquiry learning models and students 'initial ability to learn the cognitive domain of students' learning competencies?

This research is expected to increase the repertoire of knowledge, especially inquiry learning models of learning outcomes and this research is also an input and reference for other researchers who wish to follow up on this research. Also as a material consideration for teachers in choosing learning models that are used in order to improve the quality of education. And can also be taken into consideration for teachers, principals and other policy makers in determining policies on teaching biology subjects.

\section{MATERIALS AND METHODS}

This type of research is a quasi-experimental study. In the implementation, students are divided into two groups, namely the experimental class and the control class. The experimental class is a class using inquiry learning models and initial learning abilities while the control class is a conventional class using conventional learning models and initial abilities. To obtain data in this study, a research instrument in the form of a test instrument was developed. This instrument is used to assess students' initial abilities and cognitive competencies of students.

\subsection{Normality test}

Normality test aims to see whether the data distribution is normal or not. Normality test is carried out using the Kolomogorov-Smirnov test using SPSS 17. The data is normally distributed if the value of $\alpha$ obtained is greater than the significance level of 0.05 . The statistical hypothesis is as follows:

$\mathrm{H} 0$ :data follows a normal distribution

$\mathrm{H} 1$ :data does not follow a normal distribution

The test criterion is accept $\mathrm{HO}$ if the significance value is significant $(\alpha=0.05)$ means that it is normally distributed 
otherwise. The analysis is used by using SPSS 17 software.

\subsection{Homogeneity Test}

Homogeneity variance test was conducted to see the diversity of students' knowledge of both groups (experiment and control). If Fcount $\leq$ Ftable then $\mathrm{H} 0$ is accepted, it can be said that the data comes from a homogeneous population, and vice verse if Fcount $\geq$ Ftable, it can be said that the data comes from a population that is not homogeneous[6]. The analysis is used by using SPSS 17 software.

\subsection{Two-way analysis of variance (ANAVA) test}

Two way anova is also called multivariate anova which is used to test many groups of samples involving multiple classifications (more than one dependent variable). This test is carried out with the aim to determine whether there is an interaction between the learning model with the initial ability of student learning outcomes. The analysis is used by using SPSS 17 software.

\subsection{Test the first hypothesis to the third hypothesis}

The first hypothesis test to the third hypothesis is used to determine the effect of inquiry learning models and initial abilities on the cognitive competence of students. Testing the first hypothesis to the third hypothesis is done using the $t$ test if the data is normally distributed and has a homogeneous variance. The test criteria are if the significance value $>0.05$ then $\mathrm{H} 0$ is accepted and $\mathrm{H} 1$ is rejected, otherwise the significance value $<0.05$ then $\mathrm{H} 1$ is accepted and $\mathrm{H} 0$ is rejected.

\subsection{Test the fourth hypothesis}

The fourth hypothesis test is used to determine the interaction of inquiry learning models and initial abilities of the cognitive competence of students. The fourth hypothesis testing is done using two-way ANAVA test if the data is normally distributed and has a homogeneous variance. The test criteria are if the significance value > 0.05 then $\mathrm{H} 0$ is accepted and $\mathrm{H} 1$ is rejected, otherwise the significance value $<0.05$ then $\mathrm{H} 1$ is accepted and $\mathrm{H} 0$ is rejected.

\section{RESULT AND DISCUSSION}

\subsection{Initial ability test data}

Description of research data on the students' initial ability test in learning biology consists of two groups, namely data on the results of the initial ability test of the experimental group students and the data on the results of the initial ability test of the control class students. A description of the initial ability variable research data can be seen in Table 2 .

Table 2. Description of Initial Capability Data

\begin{tabular}{|l|l|l|}
\hline \multirow{2}{*}{ Parameter } & \multicolumn{2}{|l|}{ Initial Capability } \\
\cline { 2 - 3 } & Experiment & Control \\
\hline Mean & 73,12 & 72.47 \\
\hline
\end{tabular}

\subsection{Data learning outcomes}

Description of research data variable learning outcomes cognitive domains of students as a whole reveal information about the average value (mean), the results of the normality test and homogeneity test results of the study, for summary data can be seen in Table 3 as follows.

Table 3. Description of average value data, normality test results and homogeneity tests.

\begin{tabular}{|c|c|c|c|c|c|c|c|}
\hline $\begin{array}{l}\mathrm{P} \\
\mathrm{a} \\
\mathrm{r}\end{array}$ & \multicolumn{2}{|c|}{$\begin{array}{l}\text { Data } \\
\text { learni } \\
\text { ng }\end{array}$} & \multicolumn{2}{|c|}{$\begin{array}{l}\text { Data learning } \\
\text { outcomes } \\
\text { experiment }\end{array}$} & \multicolumn{2}{|c|}{$\begin{array}{c}\text { Data } \\
\text { learning } \\
\text { outcomes } \\
\end{array}$} & \multirow{2}{*}{$\begin{array}{l}\text { Expla } \\
\text { nation }\end{array}$} \\
\hline $\begin{array}{l}\mathrm{a} \\
\mathrm{m} \\
\mathrm{e}\end{array}$ & $\begin{array}{l}x \\
p\end{array}$ & $\begin{array}{l}\mathrm{C} \\
\mathrm{o}\end{array}$ & High & Low & High & Low & \\
\hline $\begin{array}{l}\mathrm{M} \\
\mathrm{e} \\
\mathrm{a} \\
\mathrm{n}\end{array}$ & $\begin{array}{l}9 \\
8 \\
\end{array}$ & 1 & 79,7 & 80 & 70 & 68,3 & $\begin{array}{c}\text { Exper } \\
\text { iment } \\
>\text { Cont } \\
\text { rol } \\
\end{array}$ \\
\hline $\begin{array}{l}\mathrm{N} \\
\mathrm{o} \\
\mathrm{r}\end{array}$ & 1 & 0 & 0,2 & 0,2 & 0,2 & 0,15 & $\begin{array}{c}\text { Norm } \\
\text { al }\end{array}$ \\
\hline $\begin{array}{l}\mathrm{Ho} \\
\mathrm{mo}\end{array}$ & \multicolumn{2}{|c|}{0,481} & & 0,943 & \multicolumn{2}{|c|}{$\begin{array}{c}0,44 \\
4\end{array}$} & $\begin{array}{c}\text { Homo } \\
\text { gen }\end{array}$ \\
\hline
\end{tabular}

Table 3 shows a summary of cognitive domain learning outcomes from the experimental group getting better results from the control group learning outcomes where the experimental class averaged 79.8 and for the control class averaged 69.1. While cognitive learning outcomes of groups of students with high initial abilities scored 79.7 in the experimental class, and 70 in the control class. And for the group of students with low initial abilities, the cognitive learning outcomes obtained in the experimental class with a value of 80 , and a control class of 68.3 . From the results of the normality of the two classes, the results are obtained that the two classes of data are normally distributed, and both classes are homogeneous because they meet the homogeneity test requirements.

\subsection{Test findings /Test the first findings}

The first finding that will be tested is the cognitive competence of learners who learn using inquiry learning models is higher than the cognitive competence of students who learn by using conventional methods. Table 4 summarizes the testing of the first findings.

Table 4. Summary of the first findings

\begin{tabular}{|c|c|c|c|}
\hline Cla & M & signifi & Explan \\
\cline { 1 - 2 } Ex & 7 & 0,000 & $\begin{array}{r}\text { Experi } \\
\text { ment }>\text { Co }\end{array}$ \\
\cline { 1 - 1 } Co & 6 & & 0
\end{tabular}

From Table 4, the results of testing the findings found the average value of cognitive learning outcomes of students who learn to use inquiry learning models and cognitive competence of learning students who learn by using 
conventional methods with an average value of experimental class of 79.8 and for the control class the average value is 69.1. For the t test with the help of SPSS, the significance value obtained is 0,000 and smaller than the alpha value of 0.05 , it can be concluded that the cognitive learning outcomes of students who learn to use inquiry learning models are higher than the cognitive domains of students learning cognitive learning with using conventional methods.

\section{Test the second finding}

The average cognitive learning outcomes of students with low initial abilities taught using the inquiry learning model are higher than the learning outcomes of cognitive domains of biological students with high initial abilities taught by conventional methods. A summary of the calculation of the second finding test can be seen in Table 5 below.

Table 5. Summary of the findings of the second finding

\begin{tabular}{|c|c|c|c|}
\hline Class & Mean & significan & Explanatio \\
\hline Experi & $\frac{80}{70}$ & 0,002 & Experimen \\
\hline
\end{tabular}

In Table 5 there is an average value of the experimental class of 80 and for the control class an average value of 70 . For the $t$ test the significance value obtained was 0.002 and smaller than the alpha value of 0.05 , it can be concluded the cognitive learning outcomes of students with low initial abilities taught by using inquiry learning models higher than cognitive learning outcomes of students with high initial abilities taught by using conventional methods.

Third test findings

Biology learning outcomes of students with low initial cognitive abilities are taught by using an inquiry learning model higher than cognitive learning outcomes of students with low initial abilities taught by conventional methods. The calculation of the third finding test is summarized in Table 6 below.

Table 6. Summary of findings of the third finding

\begin{tabular}{|c|l|l|r|}
\hline Cla & M & signif & Explan \\
\cline { 1 - 2 } Exp & 8 & 0,001 & $\begin{array}{r}\text { Experi } \\
\text { ment }>\text { Co }\end{array}$ \\
\hline Con & 6 & &
\end{tabular}

The average value of the experimental class was 80 and for the control class the average value was 68.3. For the t test, the significance value obtained by 0.001 and smaller than the alpha value of 0.05 , it can be concluded that the cognitive competence of learning students with low initial ability to learn using inquiry learning models is higher than the cognitive competence learning ability of students who have early ability low learning by using conventional methods.

\section{Test the fourth finding}

There is an interaction between inquiry learning models and initial abilities towards learning outcomes in students' cognitive biology. A summary of the results of the fourth calculation can be seen in Table 7 below.
Table 7. Summary of the findings of the fourth finding

\begin{tabular}{|c|c|c|c|c|c|}
\hline $\begin{array}{c}\mathrm{s} \\
0\end{array}$ & $\mathrm{~F}$ & $\mathrm{~F}$ & $\begin{array}{l}\mathrm{s} \\
\mathrm{i}\end{array}$ & $\alpha$ & $\begin{array}{c}\text { Explanati } \\
\text { on }\end{array}$ \\
\hline L & & \multirow{17}{*}{9} & 0 & \multirow{17}{*}{$\begin{array}{l}0 \\
0 \\
0 \\
5\end{array}$} & There is \\
\hline e & $9^{2}$ & & & & \\
\hline $\mathrm{a}$ & & & & & Interaction \\
\hline $\mathrm{r}$ & 5 & & 0 & & of \\
\hline $\mathrm{n}$ & & & 0 & & Learning \\
\hline i & & & & & Models \\
\hline 1 & 0 & & 0 & & There is \\
\hline it & & & , & & Interaction \\
\hline $\mathrm{i}$ & 7 & & 3 & & between \\
\hline $\mathrm{a}$ & 5 & & 8 & & Early \\
\hline 1 & & & & & Skills with \\
\hline $\mathrm{L}$ & \multirow{6}{*}{$\begin{array}{l}4 \\
9\end{array}$} & & \multirow{6}{*}{8} & & There \\
\hline e & & & & & Is No \\
\hline $\mathrm{a}$ & & & & & Interactio \\
\hline $\begin{array}{l}\mathrm{r} \\
\mathrm{n}\end{array}$ & & & & & $n$ of \\
\hline $\mathrm{i}$ & & & & & Learning \\
\hline $\mathrm{n}$ & & & & & Models \\
\hline
\end{tabular}

Can be seen in Table 7, the interaction between the learning method variables and the initial ability is significant $=0.48$, this means the significance value $>0.05$ then $\mathrm{HO}$ is accepted. Thus it can be concluded that there is no interaction between the learning model of inquiry models and the initial ability of students' cognitive learning competencies.

Improved learning outcomes of the cognitive domain of students taught by inquiry learning models provide opportunities for students to develop their abilities in learning. The difference in the use of inquiry learning with direct learning or lectures is that in the inquiry learning students are given the opportunity to experiment, discuss, express old or new ideas to build knowledge in their minds[7]. So basically the students themselves solve the problems given through the guidance process by the teacher. Problems that are solved through critical thinking of students are given reinforcement, so that students not only remember but also understand more deeply about the problem. It can be concluded, with the application of inquiry learning can improve the competence of students. The results of the increase in the significance of the learning outcomes of experimental class students who were taught with practicum-based inquiry learning models compared to control class students who were taught with conventional learning on excretory system material[8]. 
So it can be concluded that inquiry learning can improve students' cognitive domain competencies. The experimental class uses guided inquiry learning with multirepresentations and the control class uses guided inquiry learning[9]. The results of the study showed that the science process skills of the experimental class students were not different from the control class students, while the mastery of science concepts in the experimental class students differed from the control class students, and the students' science process skills were positively correlated with the mastery of the concepts of science.

Test findings also prove the inquiry method provides an effect on cognitive learning outcomes of students with high initial knowledge as well as students with low initial knowledge in the sense that students with high and low initial knowledge taught with inquiry learning models obtain better cognitive learning outcomes than students who are taught using conventional methods.

The calculation results for testing the findings conclude there is no interaction between the use of inquiry learning models and students 'initial ability to learn outcomes of students' cognitive domains. That is, there is no joint contribution that can be contributed between learning models and initial abilities towards learning outcomes of students' cognitive domains. There is no interaction between the learning model and the initial ability of students' learning motivation[10]. There is no interaction between the learning model and the initial ability to understand concepts[11].

\section{CONCLUSION}

Based on the results of the study, the following conclusions can be drawn.

There is a difference between the learning outcomes of the cognitive domain of students who learn to use the inquiry learning model and students who learn using conventional methods in class VIII at SMPN 12 Padang.

There is a difference in the learning outcomes of cognitive domains of students who have low initial abilities who learn to use inquiry learning models with high-ability early learners who learn by using conventional methods in class VIII at SMPN 12 Padang.

There is a difference in the learning outcomes of the cognitive domains of students who have low initial ability to learn using the inquiry learning model with students of knowledge domain who have low initial ability who learn by using conventional methods in class VIII of SMPN 12 Padang.

There is no interaction between the use of inquiry learning models and the initial ability of learning competencies in the cognitive domain of students of class VIII at 12 Padang State Junior High School.

\section{REFERENCES}

[1] Hamzah B. Uno. (2011). Orientasi Baru dalamPsikologi Pembelajaran.Jakarta:Bumi Aksara.
[2] Yamin,

M.

2012.

Strategi

PembelajaranBerbasis

Kompetensi.

Jakarta:Referensi (GP Press Group).

[3] Putra, S. R. 2013. Desain Evaluasi Belajar Berbasis Kinerja. Yogyakarta: DivaPress.

[4] Mardiansyah, Y. (2013). Pembuatan Modul Fisika Berbasis TIK untuk Mengintegrasikan Nilai Pendidikan Karakter dalam Pembelajaran Siswa SMAN 10 Padang Kelas X Semester 1. Pillar of Physics Education, 1(1).

DOI: http://dx.doi.org/10.24036/487171074

[5] Kunandar. 2013. Guru Profesional. Jakarta. Rajawali Press.

[6] Sudjana. 2011.Penilaian Hasil Proses Belajar Mengajar. Bandung: PTRemaja Rosdakarya.

[7] Tangkas, M. 2012. "Pengaruh ImplementasiModelPembelajaranInkuiriTer bimbing Terhadap KemampuanPemahamanKonsepDanKetera mpilan Proses SainsSiswa KelasX SMAN 3Amlapura".Tesis.

ProgramPascaserjanaUniversistas

Pendidikan Ganesha.

[8] Hanim.2015.PenerapanPembelajaranInkuiri terbimbingberbasispraktikum pada materi sistem ekskresi untuk meningkatkan hasil belajar kognitif pesertadidik SMA. JurnalEduBio Tropika,3 (1), 1-50.

[9] Rizal, M. M. 2014."Pengaruh PembelajaranInkuiri Terbimbingdengan Multi

RepresentasiterhadapKeterampilan ProsesSainsdanPenguasaan Konsep IPA SiswaSMP”. JurnalPendidikan Sains. 2 (3), 159-165

[10] Rizkiana, Fitria., Dasna, I Wayan. \& Marfu'ah, Siti. 2016. Pengaruh Praktikum dan Demonstrasi Dalam Pembelajaran Inkuiri Terbimbing terhadap Motivasi Belajar Siswapada Materi Asam Basa Ditinjau dari Kemampuan Awal. Jurnal Pendidikan: Teori, Penelitian, dan Pengembangan Volume: 1 Nomor: 3 Bulan Maret Tahun 2016 Halaman: 354-3. 
[11] Laratu, Wahyuni N., Darsikin. \& Wahyono, Unggul. 2016. PengaruhModel Pembelajaran Kooperatif Tipe STAD Berbasis Media Animasi Dan Kemampuan Awal Terhadap Pemahaman Konsep Listrik Dinamis Siswa SMA Negeri 8 Palu. eJurnal Mitra Sains, Volume 4 Nomor 2, April 2016 hlm 78-85. 